\title{
HUKUM TOLERANSI KELOMPOK SALAFI TERHADAP KELOMPOK ISLAM LAINNYA DI KABUPATEN BANYUMAS
}

\author{
Abdul Rohman dan Elis Puspitasari \\ Fakultas ISIP Universitas J enderal Soedirman Purwokerto \\ E-mail: rohman16533@yahoo.co.id
}

\begin{abstract}
Islam as a religion has a doctrine full final, complete, comprehensive and universal, so that the texts that became the guiding principle is universally viewed as well. In the real level, especially in need of interpretation, often leading to problems of its own because each group has a flow that allows the results are different interpretations. This is like the Salafi group based its interpretation on groups considered heretical Islamic sects other, so that a constraint when a dialogue about the development of tolerance values. Despite the rejection of the dialogue is actually contrary to the Qur'an itself.
\end{abstract}

Key words: Salafi, tolerance, interpretation, heretical innovation

\begin{abstract}
Abstrak
Islam sebagai agama terakhir memiliki ajaran yang lengkap, sempurna, komprehensif dan universal, sehingga nash-nash yang menjadi pedomannya banyak ditampilkan secara universal pula. Dalam tataran riil, terutama yang membutuhkan interpretasi, sering menimbulkan problem tersendiri karena masing-masing kelompok aliran memiliki interpretasi yang memungkinkan hasilnya berbeda. Hal ini seperti kelompok Salafi yang berdasarkan interpretasinya menganggap bid'ah pada kelompok aliran Islam lainnya, sehingga menjadi kendala ketika berdialog mengenai pengembangan nilai-nilai toleransi. Meskipun sebenarnya penolakan dialog itu bertentangan dengan Al Quran itu sendiri.
\end{abstract}

Kata Kunci : Salafi, toleransi, interpretasi, bid'ah

\section{Pendahuluan}

Islam sebagai agama rahmatan lil'alamin memiliki ajaran yang shoheh fi kulli zamanin wa makanin (benar pada setiap waktu dan tempat) tereduksi oleh dominannya penafsiran doktrin syari'ah ketika dihadapkan pada perbedaan penafsiran pada kehidupan sosial, sehingga menjadikan sikap keagamaan para jamaah kelompoknya sangat terbatas bila berinteraksi dengan kelompok aliran keagamaan lainnya. Namun demikian, mereka berinteraksi dengan kelompoknya sendiri mereka sangat akrab. Hal ini dapat memicu tumbuhnya sikap-sikap intoleransi dalam kehidupan sosial dan keagamaan, sebagaimana dinyatakan oleh Zulkarnain bahwa secara normatif doktriner, setiap agama selalu mengajarkan kebaikan, cinta-kasih dan kerukunan. Dalam kenyataan sosiologis, agama justru sering memperlihatkan wajah konflik yang tak kujung reda, ketegangan dan kerusuhan.
Sebagai contoh adalah konflik yang terjadi baru-baru ini di beberapa daerah di Indonesia seperti di Sambas, Aceh, Kupang, Ambon dan beberapa daerah lainnya, yang mengakibatkan kerugian yang besar baik berupa material mau pun nyawa, moral dan immaterial yang dipicu oleh komunitas antarumat beragama ${ }^{1}$. Oleh karena itu upaya mewujudkan nilai-nilai toleransi baik secara institusional, pemikiran maupun aktifitas amaliyah kolektif sangat diperlukan.

Aliran keagamaan yang tumbuh di Indonesia demikian banyak. Masing-masing aliran membawa ideologi keagamaan sendiri-sendiri yang merupakan hasil interpretasi dari pemahaman kelompoknya. Perbedaan ini sebenarnya sebagai suatu pluralitas dalam satu agama.

\footnotetext{
Zulkarnain S., dkk., "Model Interaksi Sosial Antarumat Beragama Studi Kasus Umat Beragama di Pulau Enggano", J urnal Istiqro', Vol. 02, No. 1, 2003, J akarta, Direktorat PTAl, Depag RI, hlm. 31.
} 
Apabila perbedaan itu disebabkan karena agama, bukan karena interpretasi, maka pluralisme mudah untuk diwujudkan, karena landasan pijakannya jelas berbeda, apalagi ketika diaplikasikan di Indonesia yang menganut asas demokrasi, di mana menganut dalam suatu agama direfleksikan sebagai kebebasan nurani yang paling hakiki².

Kehidupan antar aliran agama dalam Islam mempunyai perspektif yang berbeda, sebagaimana ketika dihadapkan pada kondisi-kondisi riil dalam kehidupan kelompok keagama-an yang terkait dengan kehidupan sosial keagamaan, sehingga membutuhkan penafsiran nash atau ayat. Dalam kerangka penafsiran ini tidak jarang muncul perbedaan yang signifikan, yang dapat mengakibatkan dalam perjuangan melaksanakan doktrin-doktrin syari' at menjadi berbeda antara kelompok keagamaan yang satu dengan yang lainnya. Perbedaan ini berpengaruh pada komitmen perjuangan dalam rangka menyebarkan kebenaran keyakinan ajaran Islam.

Agama, dalam perjalanan sejarahnya, selain alat pemersatu sosial, juga dapat menjadi sumber konflik. Kenyataan ini, dapat ditemukan landasan historinya sampai sekarang bahwa setiap terjadinya konflik selalu mengatasnamakan agama. Kenyataan ini agaknya sudah menjadi tradisi yang tumbuh dari agama-agama pada kehidupan sosial. Benturan agama tidak lagi bisa dielakkan, ketika pemeluk agama mengekspresikan kebenaran agamanya secara monolitik dan eksklusif. Artikulasi subyektifitas keyakinan dan kebenaran yang diyakininya seringkali menafikan kebenaran pihak lain. Padahal apabila direnungkan, dalam satu agama saja sangat sulit untuk menemukan kebenaran tunggal dalam memahami realitas teks (kitab suci). Menurut Taufik Abdullah, bahwa semakin seseorang berkonsolidasi dalam keyakinan suatu agama sesungguhnya membuat batas yang tegas antara "kita" dan "mereka" ${ }^{3}$. Hal ini menyangkut rep-

\footnotetext{
2 Abu Hafsin, "Demokrasi Di Indonesia, Antara Pembatasan dan Kebebasan", Jurnal Analisa Pengkajian Masalah Sosial Keagamaan, Vol. XVII, No. 01, Januari-J uni 2010, Semarang, Balai Penelitian Dan Pengembangan Agama, hlm. 3

3 Taufik Abdullah, "Di Sekitar Masalah Agama Dan Kohesi Sosial: Pengalaman Dan Tantangan", Jurnal Masyarakat
}

resentasi dari cerminan agama-agama yang berbeda satu sama lain.

Abudin Nata memetakan keragaman pemikiran Islam di Indonesia menjadi 12 (dua belas) macam, yang masing-masing mempunyai ciri khas dan karakter sendiri-sendiri. Kedua belas macam tersebut adalah Islam Fundamentalis, Islam Teologis-Normatif, Islam Eksklusif, Islam Rasional, Islam Transformatif, Islam Aktual, Islam Kontekstual, Islam Esoteris, Islam Tradisionalis, Islam Modernis, Islam Kultural dan Islam Inklusif-Pluralis. Setiap pemikiran dari semua aliran keagamaan memiliki nilai kele-bihan dan kekurangan, sehingga tidak pada tempatnya dan tidak bijaksana jika faham pemikiran yang satu menganggap paling unggul dan benar sedang pemikiran dari kelompok aliran keagamaan yang lainnya adalah keliru serta salah.

Persoalan yang muncul adalah ketika interpretasi setiap aliran keagamaan masing-masing mengaku paling benar, padahal hasil interpretasi tersebut saling bertentangan dan kemudian tidak dapat dikompromikan, apalagi hasil penafsiran tersebut diakuinya sebagai doktrin agama yang apabila tidak dilaksanakan mereka merasa berdosa. Inilah titik rawan dari sebuah penafsiran agama yang dapat menum-buhkan konflik horisontal dalam kehidupan masyarakat agama. Oleh karena itu, sering terjadi dalam kehidupan masyarakat adanya suatu penyerangan terhadap kelompok aliran keagamaan yang dianggap sesat, provokasi untuk membenci kelompok aliran yang dianggap radikal, dan atau provokasi terhadap kelompok yang dianggap suka menyebarkan ajaran bid'ah. Contoh riil adalah kejadian penyerangan terhadap pondok pesantren Yayasan Pesantren Islam (YAPI) Pasurusan pada pertengahan Februari 2011 oleh para santri dari ponpes yang lainnya, dan ternyata adalah bukan penyerangan yang pertama, tetapi sudah beberapa kali terjadi. Menurut Ketua Yayasan YAPI bahwa penyerangan itu lebih disebabkan oleh perbedaan ideologi (madzhab) yang dianut oleh Ponpes YAPI. Selain itu, kekerasan terhadap pengikut Al Qiyadah di Sumatra Barat, Ahmadiyah di Cianjur dan Lombok.

Dan Budaya, Vol 11, No. 1, 2009, Jakarta, LIPI, Pusat

Penelitian Kemasyarakatan Dan Kebudayaan, hlm. 3. 
UUD 1945 sesungguhnya memberi ruang bagi perbedaan tafsir, sejauh menjalankan ibadah itu dilakukan dengan tertib dan damai, tidak ada hak-hak yang dilanggar. Namun demikian, ruang untuk berbeda tafsir di sini dinihilkan dan yang tersisa adalah yindak kekerasan yang melawan hukum seperti pembakaran, pengusiran dan pengucilan. Negara melalui aparatnya melakukan pembiaran (omission) dan juga intimidasi ${ }^{4}$.

Lebih mengerikan lagi adalah bahwa tindakan provokasi untuk menumbuhkan kebencian, penyerangan dan atau pembakaran tempat ibadah itu dilakukan atas dasar doktrin agama, yakni jihad. Apabila semua aliran keagamaan meyakini apa yang dilakukannya adalah representasi dari jihad, maka konflik horisontal tidak dapat dihindarkan lagi. Agama yang dipahami secara sempit dan para pemeluknya bersifat eksklusif, maka agama akan menj adi sumber konflik, sebaliknya apabila pemeluk agama dapat menerima perbedaan sebagai ketentuan Tuhan dan karena itu dapat saling menghargai sesama pemeluk agama satu dengan lainnya, maka agama dapat menciptakan keda-maian. ${ }^{5}$

Berdasarkan laporan dari United Nation Support Facility to Indonesian Recovery (UNSFIR) yang berjudul Patterns of Collective Violence in Indonesia 1999-2003 menunjukkan bahwa tingkat tingginya kekerasan komunal di Indonesia, yakni mencapai angka 89,3\% Dalam peristiwa kekerasan itu, kekerasan antar agama maupun di dalam agama yang sama, dengan aliran atau kelompok yang berbeda merupakan jenis kekerasan yang paling banyak terjadi dan menyebar di hampir seluruh provinsi di Indonesia. ${ }^{6}$ Hal ini dikuatkan oleh hasil kajian Afif Muhammad, tentang Radikalisme Agama-Agama Abad 21, bahwa agama sebenarnya menjanjikan perdamaian dan menyerukan keselamatan, te-

\footnotetext{
4 Todung Mulya Lubis, "Menegakkan Hak Asasi Manusia, Menggugat Diskrtiminasi", J urnal Hukum Dan Pembangunan, Th. Ke-39, No. 1, J anuari 2009, J akarta, UI, hlm. 64-65.

5 Murniati Mawardi, "Corak Kerukunan Umat Kristen Dan Umat Islam Di Kelurahan Naikolan Provinsi NTT", Analisa J urnal Pengkajian Masalah Sosial Dan Keagamaan, Vol. XVI, No. 2, J uli-Desember 2009, Semarang, Balai Penelitian dan Pengembangan Agama, hlm. 215.

6 Mukhsin Jamil, 2008, Agama Agama Baru Di Indonesia, Yogyakarta, Pustaka Pelajar, Cet. I, hlm. viii
}

tapi pada saat yang sama ia sering menebar kekerasan. Sesekali agama dapat merupakan faktor pemersatu, dan pada saat yang lain ia dapat mencabik-cabik persatuan yang dianjurkannya. ${ }^{7}$ Kepentingan agama dan kepentingan umat beragama dalam kehidupan sosial bahkan seringkali menjadi tumpang tindih. Di sinilah ketegangan, bahkan konflik di Indonesia yang terkait dengan masalah agama dengan keumatan dapat dipetakan menjadi lima kategori keteganagn atau konflik keagamaan, yaitu intern aliran; lintas aliran dalam satu agama; lintas agama; agama dan kepercayaan lokal serta agama dan negara. ${ }^{8}$

Kondisi seperti tersebut adalah suatu kenyataan yang terjadi di bumi pertiwi, termasuk di wilayah-wilayah kabupaten seperti Banyumas. Gesekan, ketegangan, kekerasan, dan konflik yang dipicu oleh kelompok aliran keagamaan merupakan pemandangan yang sering terjadi. Islam yang universal, inklusif, toleran, demokratis dan menjunjung tinggi nilai-nilai keadilan telah difahami oleh kelompok-kelompok aliran keagamaan menjadi Islam yang lokal, sempit, kaku dan keras. Islam sebagai agama yang penuh rahmat, belum memberikan keberdayaannya dalam ranah yang lebih riil.

Potret seperti itulah menjadi penting untuk dikaji dan dikembangkan nilai-nilai toleransi yang ada dalam kelompok aliran keagamaan Islam. Salah satu di antara sekian banyak aliran dalam Islam adalah kelompok Salafi. Kelompok ini mempunyai karakteristik tersendiri. Aktifitasnya lebih eksklusif dan pandangan-pandangannya mengarah pada ideologi kaum puritan dalam mengantisipasi perkembangan zaman. Melihat kelompok aliran dalam Islam yang demikian tumbuh di Indonesia, maka alangkah indahnya apabila antar kelompok aliran saling bersilaturrahmi, berinteraksi, berdiskusi tentang syari' at atau persoalan-persoalan duniawi.

\footnotetext{
7 Afif Muhammad, "Radikalisme Agama Agama Abad 21", Al Jami'ah, J ournal of Islamic Studies, Vol. 41, Number 02, Tahun 2003, Yogyakarta - Indonesia, IAIN, hlm. 309.

8 Mujahirin Thohir, "Fundamentalisme Keagamaan Dalam Perspektif Kebudayaan", J urnal Analisa, Vol. XVII, No. 02 Juli - Desember 2010, Balai Litbang Agama, Semarang, hlm. 166
} 
Tulisan ini akan menelaah persoalan sisi teoritik dari pandangan kelompok Salafi dalam mengimplementasikan nilai-nilai toleransi dengan kelompok aliran Islam lainnya baik secara riil melalui interaksi individual maupun komunal, atau secara intelektual melalui diskusi dan atau tukar pendapat dalam menghadapi persoalan umat. Aplikasi amaliyah suatu kelompok aliran tidak lepas dari konsep teoritik atau hukum yang dikemukakannya.

\section{Pembahasan \\ Peluang Islam Sebagai Ajaran yang Mem- bangun Nilai-Nilai Toleransi}

Islam sebagai agama terakhir yang diturunkan Allah, diakui umatnya sebagai ajaran yang lengkap, sempurna, komprehensif dan universal. Akibat dari sifat-sifatnya itu maka ajaran Islam ini berlaku sepanjang masa, di segala tempat, dan tidak dibatasi oleh sekatsekat kultural, budaya, maupun bangsa. Islam sebagai ajaran yang universal, maka banyak nash yang sifatnya umum, dan tidak applicated pada persoalan sosial yang sifatnya sangat operasional, memunculkan problem tersendiri. Masalah ini sering memunculkan ketegangan sosial, meskipun sebenarnya memberikan ruang gerak interpretasi yang lebih berkembang.

Peran agama, apabila dilihat dalam kehidupan manusia, maka mempunyai keterika-tan tersendiri. Pada tataran teoritis, ada dua konsep yang dapat memperngaruhi para pemeluknya dalam berhubungan di antara mereka, yakni fanatisme dan toleransi. Kedua konsep ini hendaknya dipraktekkan dalam pola yang seimbang. Apabila fanatisme terlalu kuat, sementara toleransi lemah, maka yang muncul adalah sikap permusuhan terhadap pemeluk lain. Namun jika toleransi yang dominan, maka eksistensi akan melemah, karena dalam situasi seperti itu para pemeluk agama tidak lagi merasa bangga dengan agama yang dipeluknya?

Di Indonesia, praktik toleransi mengalami pasang surut. Pasang surut ini dipicu oleh pemahaman distingtif yang bertumpu pada relasi "mereka" dan "kita". Dalam kaitan ini, sering

\footnotetext{
9 Endang Turmudi dan Reza Sihbudi, 2005, Islam Dan
} Radikalisme Di Indonesia, J akarta: LIPI Press, hlm. 6. dikemukakan bahwa, radikalisme, ekstremisme, dan fundamentalisme merupakan baju kekerasan yang ditimbulkan oleh pola pemahaman yang eksklusif dan anti dialog atas teks-teks keagamaan. Seluruh agama harus bertanggung jawab untuk mewujudkan keadilan dan kedamaian. Hal ini tidak akan tercapai hanya dengan mengandalkan teologi eksklusif yang hanya berhenti pada klaim kebenaran, tetapi membutuhkan teologi inklusif yang menjunjung nilai-nilai pluralism, yang berorientasi pada pembebasan.

Islam, dalam ranah toleransi, sebenarnya telah memberikan dasar teologis yang sangat mendasar. Setiap orang bebas untuk memilih dan menjalankan agamanya sesuai dengan keyakinannya. Bagi manusia disadari atau tidak, adalah berasal dari sumber yang sama yakni Tuhan. Oleh karena itu sangat tidak elegan jika antara yang satu dengan yang lainnya saling bersitegang, membenci, konflik dan melakukan tindakan anarkis. Termasuk di dalamnya adalah memicu munculnya perbuatan-perbuatan yang dapat menimbulkan konflik, bahkan yang diajarkan agama adalah menaburkan kasih sayang, kedamaian (salam), kepedulian dan saling mengenal antar sesama.

Islam, dalam ranah hukum, juga memberikan ruang gerak yang dinamis. Hal ini terlihat dari penampilan nash Al Quran yang banyak memberikan dzann (dugaan) terutama dalam persoalan mu'amalah, jika dibandingkan dengan ayat-ayat yang bersifat qath'i (pasti) terutama dalam persoalan ibadah. Ayat-ayat yang bersifat dzann ini dikemukakan dengan bahasa yang tidak tegas, memiliki banyak arti yang memungkinkan untuk ditafsirkan dengan makna lain (interpretable) atau disebut dengan ayat mutasyabihat. Teks-teks tidak tegas inilah yang menjadi lahan penggalian hukum dalam menyelesaikan berbagai persoalan kehidupan manusia yang tidak ditemukan jawabannya di dalam Al Quran maupun Al Hadits ${ }^{10}$. Dengan demikian, meskipun ajaran agama telah memberikan nuansa yang besar bagi pengembangan nilai-nilai

\footnotetext{
${ }^{10}$ Titik Tri Wulan Tutik, "Analisis Hukum Islam terhadap Praktek Aborsi Bagi Kehamilan Tidak Diharapkan (KTD) Akibat Perkosaan Menurut Undang-Undang No. 36 Tahun 2009 Tentang Kesehatan", Jurnal Hukum Dan Pembangunan, Tahun ke-35, No. 2, April 2010, hlm. 203.
} 
toleransi, tetapi dalam kenyatannya, sering muncul ketegangan, disharmoni, dan atau konflik yang berangkat dari agama atau klaim interpretasi kebenaran agama itu sendiri. Masalah sosial, ekonomi, budaya, politik, maupun hegemoni penguasa juga ikut mewarnainya. Salah satu cara untuk menanggulangi persoalan tersebut adalah upaya memunculkan pemikiran, interpretasi, sikap, tindakan yang didasarkan pada nilai-nilai demokrasi dan inklusivitas.

Pada saat sebagian kelompok Islam ingin menampilkan Islam yang inklusif, dari sisi lain khususnya gerakan Salafi, yang di masa Ialu hanya sebagai varian kecil, tiba-tiba muncul sebagai raksasa corak kelslaman yang dalam gerakannya selalu mengedepankan teks dari pada konteks, bukan hanya mendekonstruksi terhadap apa yang disebut "Barat", tetapi juga menyudutkan Islam inklusif, toleran, adaptif dan setia pada tradisi ${ }^{11}$. Persoalan sosial yang ada dalam kehidupan masyarakat demikian kompleks, maka pengembangan nilai-nilai toleransi dalam rangka memunculkan kehidupan yang damai, harmonis, setara dan adil lebih memungkinkan dari pada pengembangan cara lainnya.

Toleransi sebagai sikap manusia adalah muncul bukan karena faktor keterpaksaan, tetapi benar-benar muncul dari kesadaran hati yang paling dalam. Sikap inilah yang menjadi landasan utama bagi terciptanya wadah bersama bagi kelompok aliran agama. Dalam suatu perbedaan interpretasi dari kelompok aliran keagamaan yang masing-masing mengakui memiliki kebenaran, bahkan mengakuinya seba-gai paling benar, kemudian saling bertabrakan, maka bukan jalan formal seperti pengadilan, hegemoni penguasa untuk menghanguskan eksistensinya, melainkan jalan negosiasi, melalui pendekatan hati, pengembangan nilai-nilai toleransi jauh lebih elegan. Pertentangan interpretasi yang dapat memunculkan konflik pada hakekatnya merupakan perbedaan penafsiran nash yang suci, sehingga cara-cara penyelesaianpun dilakukan dengan cara-cara yang baik dan suci.

\footnotetext{
${ }^{11}$ Anas Saidi, "Relasi Pancasila, Agama Dan Kebudayaan, Sebuah Refleksi", Jurnal Masyarakat Dan Budaya, Vol 11, No. 1/2009, Jakarta, LIPI, Pusat Penelitian Kemasyarakatan Dan Kebudayaan, hlm. 43.
}

Islam sebagai agama terakhir yang diturunkan Allah diakui umatnya sebagai ajaran yang lengkap, sempurna, komprehensif dan universal. Akibat dari sifat-sifatnya itu, maka ajaran Islam ini berlaku sepanjang masa, di segala tempat, dan tidak dibatasi oleh sekat-sekat kultural, budaya, maupun bangsa. Islam, sebagai ajaran yang universal, maka banyak nash yang sifatnya umum, dan tidak applicated pada persoalan sosial yang sifatnya sangat operasional, memunculkan problem tersendiri. Masalah inilah yang sering memunculkan ketegangan dan konflik sosial.

Upaya pengembangan nilai-nilai toleransi di kalangan kelompok-kelompok aliran keagamaan dalam Islam adalah pembentukan forum yang dijadikan media dalam merealisirnya. Forum ini adalah sebagai media komunikasi dan wadah silaturahmi intelektual. Tujuannya adalah untuk pengembangan nilai-nilai toleransi, moderasi, demokrasi, kesetaraan dan keadilan di antara kelompok aliran keagamaan yang didasarkan pada interpretasi nash agama. Kepentingan bersama lebih didahulukan. Dalam proses mendahulukan kepentingan bersama, ada beberapa langkah sebagai pedoman.

Pertama, bahwa setiap manusia memiliki hak untuk melaksanakan ajaran Islam secara total. Kedua, kebenaran interpretasi manusia terhadap nash adalah relatif. Hal ini dibuktikan dalam sejarah Islam, di mana perbedaan-perbedaan interpretasi merupakan wacana intelektual yang menakjubkan. Munculnya kitab Madzahibul Arba'ah (Interpretasi agama menurut 4 Madzhab, yakni Imam Hanafi, Maliki, Syafi'i dan Hambali) karya Abdurrahman al J ujairi, merupakan bukti tentang adanya perbedaan interpretasi dalam persoalan agama dan sosial. Hal ini nampak jelas ketika para Imam tersebut menyampaikan akan relatifnya penda-pat yang dikemukakannya. Imam Abu Hanifah berkata: "Kami hanyalah seorang manusia. Hari ini kami berpendapat demikian tetapi besok kami mencabutnya"." Kemudian Imam Malik berpendapat "Saya hanyalah seorang manusia, terkadang salah, terkadang benar. Oleh karena itu, telitilah pendapatku. Bila sesuai dengan Al-Qur'an dan Sunnah, ambillah; dan bila tidak sesuai dengan 
Al-Qur'an dan As Sunnah, tinggalkanlah". Kemudian Imam Syafi'I juga berkata: "Bila kalian menemukan dalam kitabku sesuatu yang berlainan dengan Hadits Rasulullah, peganglah Hadits Rasulullah itu dan tinggalkan pendapatku itu" $^{12}$. Dengan demikian sangat tidak bijak, apabila seseorang mengkultuskan dan atau memutlakkan suatu madzhab tertentu, padahal pendirinya sendiri merelatifkannya.

Kemutlakan Tuhan, sebenarnya dapat dimaklumi bahwa selain Tuhan pasti relatif. Oleh karena itu dapat dinyatakan bahwa sesuatu yang datang dari Tuhan yakni agama juga memiliki nilai absolut. Namun demikian, pada saat manusia menyampaikan ajaran agama, sesuai kapasitasnya sebagai manusia yang terbatas, maka secara implisit harus mengakui tentang kenisbiannya dalam menangkap kebena-ran Tuhan. Sikap toleran dalam melihat setiap perbedaan yang relatif itu akan lebih bijak apabila dimiliki, sehingga tidak sepantasnya apabila dalam kehidupan masyarakat terdapat orang atau suatu aliran agama yang merasa memonopoli kebenaran dan kemudian memaksakan kepada orang lain atas nama Tuhan.

Dani Muhtada, menyatakan bahwa memahami syari'at secara proporsional kita harus melihat Islam sebagai sebuah sistem keyakinan (belief system). Sebagian orang mungkin akan menolak cara seperti ini, sebab akan dianggap mensejajarkan Islam dengan paradigma atau ideologi lain, yang merupakan produk dan rekayasa manusia (tidak seperti Islam yang merupakan rekayasa Tuhan). Perlu diingat, bahwa terdapat hal yang harus diakui, bahwa tidak ada satupun pola pemikiran Islam yang sungguhsungguh obyektif, dalam pengertian sebagaimana yang dimaksudkan Tuhan sebagai sumber ajaran. Setiap orang yang mencoba memahami Islam dalam kerangka subyektivitasnya, terlepas dari apakah subyektivitasnya itu dapat dipertanggungjawabkan secara ilmiah atau tidak,

\footnotetext{
${ }^{12}$ Syaikh Muhammad Nashiruddin Al-Albani, Pernyataan Para Imam Untuk Mengikuti Sunnah Dan Meninggalkan Yang Menyalahi Sunnah, tersedia di website http://www. google.co.id/search?hl=id\&source $=h p \& q=$ PERNYATAAN + PARA +IMAM+UNTUK+MENGIKUTI+SUNNAH+DAN+MENINGGA LKAN+YANG+MENYALAHI+SUNNAH\& met $a=\& a q=f \& a q i=\& a q I$ $=\&$ oq, diakses tanggal 7 Maret 2011.
}

sehingga ditemukan pemahaman Islam menurut pola pemikiran orang tertentu. ${ }^{13}$

Kelompok aliran keagamaan Islam di Kabupaten Banyumas memberikan pandangan bahwa toleransi itu perlu diaplikasikan dalam kehidupan nyata, bukan hanya sekedar teori. Saling menghormati dalam beribadah, menghormati peribadatan dilakukan di masjid-masjid yang di bangun oleh kelompok masing-masing, memperbolehkan kelompok lain untuk melakukan peribadatan (sholat) di masjid kelompok lain. Dalam kerangka menjaga nilai-nilai toleransi antar kelompok keagamaan Islam inilah diperlukan suatu wadah yang dapat dijadikan media silaturahmi intelektual. Kemudian dalam upaya pengembangan nilai-nilai toleransi di kabupaten Banyumas, beberapa kelompok aliran dalam Islam yaitu Hizbut Tahrir Indonesia (HTI), Islam Jamaah atau lembaga Dakwal Islamiyah Indonesia (LDII), J amaah Tabligh, Syahadatain dan Salafi melalui pertemuan yang telah difasilitasi FISIP Universitas J enderal Soedirman untuk mengadakan dialog interaktif. Namun dalam pertemuan tersebut terdapat satu kelompok yang tidak berkenan hadir yaitu kelompok aliran Salafi. Dialog tersebut telah menggagas munculnya sebuah forum yang bernama "Forum Silaturrahmi Intelek-tual dan Sosial". Senada dengan ide tersebut Habib Muhsin, ${ }^{14}$ memberikan gagasan bahwa dalam proses perubahan menuju ke arah yang lebih baik diperlukan komunikasi da'wah melalui "dialog Islami" yaitu dialog lisan, dialog amal, dialog intelektual, dialog seni dan dialog agama.

Keberadaan suatu "wadah" sebagai media untuk merespon masalah-masalah yang mun-cul kiranya memang cukup mendesak. Rahesli Humsona, berpendapat, diperlukan suatu pengembangan lembaga mediasi lokal yang partisipatif dan melindungi (protektif), advokatif dan konsultatif bagi suatu warga agar hidup rukun, aman dan damai. Dalam mewujudkan

\footnotetext{
${ }^{13}$ Dani Muhtada, “Elaborasi Syari'at Islam Dalam Konstitusi Indonesia: Paradigma Baru", Jurnal Konstitusi, Vol. I, No. 1, Agustus 2008, Jakarta, PKKKD-FH Universitas Muhammadiyah Magelang, MK RI., hlm. 67-68

${ }^{14}$ Habib Muhsin, "Menggagas Komunikasi Da'wah Bil Hal Di Pedesaan", J urnal IImu Sosial Alternatif, Vol. IX, No. 2, Desember 2008, Yogyakarta, APMD, hlm. 147.
} 
lembaga yang mantap perlu dikembangan sinergitas antara RT/RW dengan forum-forum masyarakat lokal yang sudah ada melalui acaraacara perkumpulan sosial keagamaan yang secara khusus dibutuhkan dan dihargai. ${ }^{15}$

Pemahaman Islam yang lebih kosmopolit, komprehensif dan universal diperlukan, sehingga Islam tetap dapat memberikan peluang besar dan dapat menjadi pembimbing dalam menginternalisasikan nilai-nilai toleransi dalam kehidupan masyarakat, kemudian nilai-nilai toleransi yang dikemas dalam wacana intelektual tersebut, disosialisasikan melalui wadah "Forum Silaturrahmi Intelektual dan Sosial" menjadi nilai dasar yang menjadi acuan bagi munculnya kehidupan yang harmonis, demokratis, moderat, adil dan setara. Forum merupakan media dan alat komunikasi dalam menjalin silaturahmi intelektual dan sosial antar kelompok aliran keagamaan.

\section{Profil Kelompok Keagamaan Salafi dan Pene- rapan Hukum Terhadap Pengembangan Tole- ransi}

Pengungkapan profil kelompok aliran keagamaan Salafi ini tidak secara detail ke akarakarnya. Namun hanya berkisar pada sisi sejarah berdirinya atau masuknya ke wilayah Kabupaten Banyumas, kepengurusannya (kalau ada), jari-nganya, tujuan pendiriannya, karakteristiknya serta konsep dan hukum toleransinya. Sejarah pendirian kelompok aliran Salafi tidak diketahui secara persis kapan masuk ke wilayah Indonesia. Salafi dalam kategori dimaksud adalah mereka yang tergolong dalam suatu gerakan dakwah yang ingin meneladani perilaku dan perjuangan Nabi yang difahami secara tekstual. Dalam kategori ini ada dua kelompok Salafi yaitu Salafi Saudi, yakni mereka yang menjadi alumni perguruan tinggi di Saudi Arabia dan Salafi Yamani, yakni mereka yang menjadi alumni dari perguruan tinggi Yaman. Sebelum gerakan ini muncul, sebenarnya di Indonesia telah dikenal istilah Salafi. Hal ini lebih mengacu pada sistem pendidikan pondok pesantren

\footnotetext{
${ }^{15}$ Rahesli Humsona, "Situasi Krisis Dan Munculnya Fenomena Kekerasan", J urnal Dinamika, Vol. 6, No. 1/2006, Surakarta, Fisip-UNS, hlm. 24.
}

yang mempelajari kitab-kitab para ulama Salaf (ulama terdahulu) atau Salafus shãlih. Ulama Salaf diambil dari mereka yang hidup setelah sahabat, yaitu tergolong pada masa tabi'in dan masa tabiit tabi'in.

Menurut Ir. Syarif Basyir, Ketua Cabang Al Irsyad, bahwa dalam masalah pemikiran, Salafi terbagai menjadi menjadi 2 (dua) kelompok sebagaimana asal dari proses pembelajaran yang mereka lakukan, yaitu kelompok Salafi Saudi, dan Kelompok Salafi Yamani. Dalam kiprah pemikirannya kelompok Salafi Saudi lebih mode-rat dibandingkan dengan kelompok Salafi Yamani. Kelompok aliran Salafi masuk ke wilayah Indonesia sekitar tahun 1980-an. Kelompok ini bergerak ke pelosok kota di Indonesia, termasuk adalah di wilayah Banyumas. Salafi sebagai gerakan, merupakan suatu kelompok Islam yang berawal dari gerakan Wahabisme pada era 70-an. Dalam dialog antara penulis dengan Ketua Al Irsyad Cabang Purwokerto, Ir. Syarif Basyir, tertanggal 21 Oktober 2010, dinyatakan bahwa gerakan Salafi ini sukses dalam melakukan transformasi secara keseluruhan model-model Salafisme yang berorientasi moderat-liberal kepada model Salafisme yang puritan, konservatif dan literalis. Gerakan Salafi inilah yang kini sedang melakukan aktifitasnya secara intens di Indonesia.

Menurut Saefudin (tokoh Salafi Purwokerto) bahwa Salafi bukan sebuah kelompok, atau golongan tertentu yang diidentikkan dengan tingkatan-tingkatan struktural kepengurusan. Salafi tidak punya struktur organisasi, sehingga tidak punya ketua, sekretaris, namun mempunyai jamaah. Mereka ada di berbagai ormas keagamaan, asal mereka mengikuti petunjuk Rasulullah, para sahabat maupun para tabi'in. Dalam jamaah Salafi tidak ada senioritas dan penokohan. Salafi menganggap bahwa ulama, kiyai, para ahli, para guru, dan sebagainya merupakan panutan yang harus dipatuhi. Salafi lebih berpegang teguh pada ayat-ayat dan hadits yang suci yang disampaikan rasul Muhammad SAW dan atsar para sahabat. Namun demikian para ulama atau guru tersebut secara 
informal adalah sebagai pemimpin. ${ }^{16}$ Salafi sangat menekankan bahwa setiap orang seharusnya mengikuti jalan yang terang lagi mudah, yakni jalan yang telah ditempuh oleh para sahabat Rasulullah Sallallãhu 'Alaihi Wasallam, tabi'in dan tabi'it tabi'in, baik dalam sikap, perilaku maupun dalam memahami dienul Islam yang dibawa Rasulullah Sallallãhu 'Alaihi Wasallam. Oleh karena itu ketika menentukan imam yang akan dijadikan panutan, maka imam yang hidup pada tiga abad pertama Islam, dari para shahabat Rasulullah Sallallãhu 'Alaihi Wasallam, tabi'in (murid-murid shahabat) dan tabi'it tabi'in (murid-murid tabi'in). Salafi mengedepankan sunatur-rasul waljamaah. Dalam aplikasinya Salafi lebih cenderung menerapkan ajaran Rasul secara tekstual. Mereka hidup dalam kesederhanaan dan mengedepankan ajaran agama. Kemudian tidak hanya belajar mengaji (tadãrus) akan tetapi lebih kepada menelaah $\mathrm{Al}$ Quran. Jaringan yang dibangun adalah melalui kajian bersama antar kelompok Salafi sendiri yang dilakukan setiap hari Sabtu ke-2 setiap bulan. Kegiatan ini dipusatkan di masjid Agung "Baitus Salam" Purwokerto yang diikuti oleh jamaah dari Kabupaten Banyumas, Purbalingga, Kebu-men, Cilacap, Majenang maupun daerahdaerah sekitarnya. Kelompok ini juga mempunyai jari-ngan dengan pondok pesantren Ibnu Taimiyah yang berada di kecamatan Sumpyuh, Banyu-mas ${ }^{17}$.

Karakteristik yang dimiliki kelompok Sala$\mathrm{fi}$, sebenarnya tidak jauh berbeda dengan kaum Muslimin pada umumnya. Namun secara spesifik kelompok ini dalam kehidupan masyarakat lebih menonjol ke "Arab" nya, seperti ketika mengenakan dalam mengenakan pakaian. Terdapat beberapa karakteristik yang dapat diungkapkan. Pertama, anggota jamaah kelompok Salafi pada umumnya dari kaum Adam (ikhwan) memakai jubah dan celana congklang (di atas mata kaki). Kaum hawa (Akhwat) memakai gaun gamis dan wajah bercadar. Kedua, jamaah pria memelihara jenggot dan mencukur kumis, apabila mereka

\footnotetext{
${ }^{16}$ Endang Turmudi dan Reza Sihbudi, op.cit., hlm. 165.

17 Abdul Rohman, dkk., 2010, Pengembangan Nilai Nilai Toleransi Pada Kelompok Aliran Keagamaan Minoritas Di Kabupaten Banyumas, Laporan Hasil Penelitian, Purwokerto: Unsoed, hlm. 54.
}

menyemir rambut kepala, maka semir yang digunakan adalah selain warna hitam Ketiga, dalam peribadatan khãs, seperti sholat jamaah, kelompok Salafi sangat memelihara dengan baik dan konsisten. Keempat, tidak mau diajak dialog, meskipun dialog agama, apabila orang atau kelompok yang mengajak dialog itu dianggap telah menyimpang dari ajaran Islam yakni penuh dengan perilaku bid'ah. Kelima, dalam pemikirannya memiliki platform, yakni cenderung melakukan interpretasi literal terhadap teksteks suci agama dan menolak pemahaman kontekstual atas teks-teks agama, karena dianggap mereduksi kesucial agama; menolak pluralisme, karena mendistorsi pemahaman ajaran agama; memonopoli kebenaran atas tafsir agama, bahkan mereka menganggap dirinya sebagai pemegang otoritas penafsiran agama yang paling benar; dan memiliki korelasi dengan fanatisme, intoleransi, radikaliasme dan militansisme ${ }^{18}$. Dalam bidang pemikiran ini kelompok Salafi menjadi terlihat lebih tegas dalam memegang teks-teks agama, tetapi dalam sisi yang lain kelompok ini menjadi kaku dalam kiprah pergaulan kemasyarakatan.

Konsep pengembangan nilai-nilai toleransi diinterpretasikan oleh kelompok salafi lebih menekankan pada pengembangan toleransi yang hanya dapat distandarkan dengan apa yang pernah dilakukan Nabi Muhammad SAW, para sahabat, tabi'in dan tabiit tabi'in. Berdasarkan keterangan yang disampaikan tokoh mereka, dapat diungkapkan sebagai berikut.

Pertama, salafi tidak mempermasalahkan perbedaan yang muncul antara NU, Muhamadiyah, kemudian aliran apa pun, sepanjang yang dituju adalah Allah SWT dan Muhammad SAW sebagai Nabi akhir zaman yang menyempurnakan aj aran Islam. Menurut aliaran ini Islam tidak mengajarkan umatnya untuk menjadi umat yang pasrah dan malas, akan tetapi menjadi umat yang mau berfikir dan membaca agar manusia menjalakan sebagaimana fungsinya.

Kedua, saat ditanya tentang pengembangan toleransi umat beragama, ustadz Saefudin

\footnotetext{
${ }^{18}$ M. Sukanta, "Fundamentalisme Islam Di Timur Tengah", Mimbar IImiah Th. 16, No. 2, Desember 2006, Jakarta, Universitas Islam, hIm. 67
} 
menjawab bahwa toleransi merupakan bentuk atau rasa kecintaaan kita terhadap sesama umat manusia yang ada di dalam muka bumi ini. Toleransi ditingkatan dunia tidak begitu dipermasalahkan oleh Salafi, akan tetapi ada batas toleransi yakni ditunjukkan dengan tidak membantu urusan orang-orang kafir, tidak akan toleran dengan orang-orang yang menyimpang dari jalan sahabat dan Rasul dalam interpretasi mereka.

Ketiga, dalam menanggapi adanya aliranaliran yang banyak bermunculan akhir-akhir ini, Salafi lebih melihat fenomena tersebut sebagai hal yang wajar, karena sudah dipastikan dalam kalãmullah bahwa akan bermunculan banyak golongan dalam Islam. Sebatas aliran tersebut punya landasan yang kuat dan tidak menyimpang dari jalan sahabat dan rasul, maka masih dapat di tolerir. Akan tetapi apabila yang terjadi sebaliknya yakni menyimpang dan atau berselisih dari jalan sahabat dan rasul, maka harus segera disadarkan melalui nasihat untuk mengingatkan tentang kekeliruan yang diperbuat oleh mereka, seperti terhadap kelompok Ahmadiyah. Pemikiran Ahmadiyah itu sesat, karena menganggap ada Nabi lagi setelah Muhammad SAW. Kekeliruan ini wajib diingatkan kesalahannya karena orang-orang yang berada di dalamnya adalah orang Islam, tetapi pemikirannya yang kafir. Apabila ada pemikiran yang sesat, maka dapat dicegah dengan cara-cara yang akhsan (baik), ilmiah, dan tidak ada maksud kepentingan pribadi.

Keempat, sesama Muslim harus toleran. Kelima, apabila diundang untuk mengikuti dan menjadi nara sumber dalam dialog interaktif antar kelompok aliran keagamaan (Islam), dalam rangka mengembangkan nilai-nilai toleransi di antara kelompok aliran dalam Islam, Saefudin Zuhri menjelaskan bahwa agama itu untuk disampaikan, bukan untuk didialogkan. Salafi ada kecenderungan tidak mau dialog dalam soal agama. Namun apabila ada yang bertanya, dan benar-benar karena tidak tahu, bukan untuk menguji, maka harus dijawab berdasarkan ilmu yang diketahuinya. Oleh karena itu ketika diadakan pertemuan, baik melalui Focus Group Discussion (FGD) yang di dalamnya ada dialog interaktif maupun workshop, dalam rangka untuk membicarakan konsep toleransi secara bersama, yang terdiri dari Salafi, Hizbut Tahrir Indonesia (HTI), Jamaah Tabligh, Syahadatain, dan Lembaga Dakwah Islamiyah Indonesia (LDII), maka kelompok Salafi tidak mau datang. Mereka beralasan bahwa terdapat kekhawatiran, apabila konsep toleransi itu membawa pada keberpihakan yang menyimpang dari ajaran $\mathrm{Na}$ bi, Sahabat, Tabi'in maupun tabiit tabi'in; dan Salafi menganggap bahwa kelompok-kelompok di luar dirinya, yaitu yang diajak berdialog adalah kelompok-kelompok yang telah berbuat bid'ah, sehingga mereka tidak mau berdialog dengan kelompok yang dianggap "menyimpang" tersebut. Mereka khawatir barangkali konsep yang disampaikan kelompok-kelompok tersebut mempengaruhi dirinya, sehingga ia sendiri masuk dalam lingkaran yang menyimpang (bid'ah) juga .

Rasa kekhawatiran itulah yang menjadi sebab dari terhalangnya mereka melakukan dialog dengan kelompok lain. Secara umum gerakan kelompok Salafi ini dipengaruhi oleh gerakan Wahabi di Saudi Arabia. Pendirinya Abdul Wahab berpandangan, bahwa praktek Islam kaum Muslimin pada saat itu, termasuk yang bersifat ritual, tidak dilakukan oleh Nabi pada saat hidupnya. Oleh karena itu praktek seperti itu tidak mempunyai rujukan dari Nabi, sehingga dianggap bid'ah, dan setiap bid'ah adalah sesat dan setiap yang sesat adalah neraka tempatnya. Pola pemikiran ini mencerminkan model pemikiran yang bersifat normatif-tekstual. Bahkan Salafi sebagai kelompok yang berada di Iuar kelompok Islam Liberal, hanya mendasarkan pada otoritas teks-teks ajaran agama yaitu al Quran dan As Sunnah, tanpa melakukan pemikiran secara kontekstual ${ }^{19}$.

Pemikiran model normatif tekstual sebenarnya banyak dipengaruhi oleh pemikiran Islam yang berasal dari Timur Tengah, karena model pemikiran yang dikembangkan antara lain ditan-

\footnotetext{
${ }^{19}$ Olaf Schumann, "J ihad for Whom ?, The Radicalization of Religion as a Response to Political Oppression: From Tuskish to Indonesian Islam", Journal of Indonesian Islam, Vol. 2, No. 02, Desember 2008, Surabaya, Program Pascasarjana - Lembaga Studi Agama Dan Sosial, IAIN Sunan Ampel, hlm. 374.
} 
dai oleh adanya upaya idealisasi terhadap realitas sosio-kultural masyarakat berdasarkan petunjuk-petunjuk yang terdapat dalam Al-Quran dan As Sunnah. Realitas sosio-kultural masyarakat yang sangat beragam di dunia ini harus didekatkan dengan model agama yang tercermin dalam Al Quran, Sunnah, Shahabat, Tabi'in maupun Tabiit Tabi'in, sehingga tingkat toleransi terhadap realitas tersebut relatif rendah dan tidak jarang muncul kemudian jurang antara idealitas Islam dan realitas umat Islam itu sendiri. Model pemikiran seperti ini dapat dijumpai pada tokoh-tokoh Salafi.

Berdasarkan penjelasan tersebut, apabila suatu perbuatan meski lebih bersifat duniawi, namun tidak dipraktekkan pada zaman Nabi dapat disebut sebagai bid'ah. Dialog antar kelompok aliran ini dianggap tidak pernah terjadi pada zaman Nabi, maka bagi mereka kegiatan seperti itupun hendaklah dihindari. Hal ini juga untuk menghindari pandangan-pandangan yang dapat mengkontaminasi inter-pretasinya.

Sikap dan pandangan (fatwa) tokoh atau ulama Salafi tersebut masuk dalam kategori "hukum", sebab hukum tidak saja berarti aturan atau undang-undang, tetapi dapat berupa kitab-kitab fiqh, keputusan-keputusan Pengadilan Agama, dan fatwa-fatwa ulama, apalagi kelompok ini secara transparan sering menyampaikan bahwa banyak kelompok-kelompok keagamaan dalam Islam yang amaliyahnya berkategori bid'ah. Hukum bid'ah kelompok-kelompok aliran Islam lainnya ini, membawa konsekuensi dalam upaya mewujudkan nilai-nilai toleransi, modera-si, inklusivitas, secara bersama melalui dialog menjadi terhalang. Hal ini menafikan pandangan-pandanganya sendiri mengenai nilai-nilai toleransi yang menyatakan bahwa umat Islam itu sebagai umat yang suka berfikir, memiliki rasa cinta antar sesama Muslim karena mereka telah bersyahadat, dan perbedaan-perbedaan yang terjadi adalah sebagai hal yang wajar. Namun ketika diajak dialog baik melalui FGD maupun kegiatan workshop mereka justru menolaknya. Padahal dialog melalui FGD dan workshop dalam rangka mencari titik temu mengenai interpretasi nilai-nilai toleransi, moderasi, dan inklusivitas dalam ajaran Islam adalah dilakukan oleh lembaga perguruan tinggi yang secara akademik dapat dipertanggung-jawabkan. Penolakan ini, apabila merujuk pada Al Qur'an, maka merupakan perbuatan yang menyimpang, sebab Al Quran sangat menekan-kan dialog atau muj adalah (diskusi) dalam menyelesaikan suatu perkara. Sebagaiamana dalam surat an-Nahl : 125, yang artinya: " Serulah (manusia) kepada jalan Tuhanmu dengan hikmah dan pelajaran yang baik dan bantahlah mereka dengan cara yang baik". Pada ayat yang lain dikemukakan tentang perintah untuk bermusyawarah, dalam menyelesaikan suatu masalah, yaitu dalam Surat Ali Imran ayat 159, yang artinya: “...dan bermusyawarhlah dengan mereka dalam suatu urusan...". Sikap penolakan tersebut dapat memutuskan tali silaturrahmi antar kelompok aliran Islam.

Pandangan Salafi tersebut menunjukkan antara teoritik yang dikemukakan dengan kenyataan yang dijalankan tidak singkron. Apabila suatu kelompok Islam tertentu telah mendapatkan label atau hukum bid'ah, maka mereka boleh dibencinya. Sikap benci ini bukan karena keislamannya, tetapi karena ajaran yang dijalankannya menurut interpretasi Salafi, tidak sesuai dengan apa yang dilakukan oleh Rasulullah, para sahabat, para tabi'in maupun para tabi'it tabi'in. Pengembangan nilai-nilai toleransi di kalangan Salafi lebih menekankan pada sisi inward looking, belum pada tataran outward looking. Pandangan interpretasinya terhadap Iandasan ajaran Islam berangkat dari pola yang dikembangkan oleh tradisi kelompok mereka sendiri, lebih bersifat monolitik. Pandangan yang menuju pada satu arah ini mengakibatkan penafian terhadap pensahan interpretasi terhadap ajaran Islam yang dilakukan oleh kelompok keagamaan Islam lainnya.

Persoalan menghukumi bid'ah atau tidak bid'ah seharusnya distandardisasikan terlebih dahulu, apakah persoalan tersebut masuk dalam wilayah syari'at atau wilayah fiqh. Hal ini penting agar para kelompok keagamaan itu sejak awal siap berlapang dada (toleran) terhadap sikap yang dianut orang atau kelompok 
lain. ${ }^{20}$ Syari'ah adalah peraturan yang ditetapkan Allah, agar dengannya manusia dapat berhubungan dengan Allah, sesama manusia dan dengan alam semesta. Dalam syari'at telah mencakup aspek aqidah, ibadah maupun akhlaq. Adapun figh berarti faham dan kecerdasan memahami sesuatu. Dalam pengertian istilah fiqh adalah memahami hukum-hukum syara' yang berhubungan dengan perbuatan manusia yang direduksi dari dalil-dalil yang terinci. Oleh karena itu dalam figh ada rasionalisasi manusia dalam memahami syari'at yakni bagaimana mengaktualisasikan syari'at dalam tataran praktis. ${ }^{21} \mathrm{Hal}$ tersebut dapat dicontohkan bahwa puasa adalah wajib dan semua ulama sepakat dan tidak ada yang membantahnya, karena ini wilayah syari'at. Lain halnya tentang awal atau akhir dari bulan Ramadhan, di mana hal tersebut merupakan wilayah figh, sehingga memungkinkan untuk berbeda pendapat dalam penentuannya. Oleh karena itu, hendaknya perbedaan itu disadari oleh semua kelompok Islam dengan lapang dada, sebab sampai kapanpun perbedaan itu sulit dipersatukan. Orang boleh berpuasa lebih awal atau berbuka lebih akhir, asalkan landasan atau argumentasinya kuat.

\section{Penutup Simpulan}

Islam sebagai agama terakhir memiliki ajaran yang lengkap, sempurna, komprehensif dan universal. Dalam tataran riil, terutama yang membutuhkan interpretasi nash agama, cenderung memunculkan permasalahan tersendiri. Permasalahan inilah yang sering memunculkan ketegangan dan konflik sosial, meskipun ayat-ayat yang bersifat universal tersebut sebenarnya memberikan ruang gerak interpretasi yang lebih berkembang.

Keberadaan kelompok keagamaan dalam Islam seperti Nahdlatul Ulama, Muhammadiyah, HTI, LDII, Jamaah Tabligh, Al Irsyad, bagi Salafi

\footnotetext{
${ }^{20}$ Aziz Fahrurrazi, "Sistem Pendidikan Pondok Pesantren Dan Tantangannya Di Era Globalisasi", Mimbar IImiah Vol. 14, No. 2, Desember 2004, J akarta, Universitas Islam, hlm. 4.

${ }^{21}$ Abdul Kholik Latuconsina, "Hukum Islam dan Eksistensi Peradilan Agama Di Indonesia, Suatu Pendekatan Sosiohistoris", J urnal Reformasi Hukum Vol. XI, No. 2, Desember 2008, J akarta, Universitas Islam, hlm. 122.
}

tidak ada masalah. Sepanjang yang dituju adalah Allah SWT dan Rasul Muhammad SAW dan aplikasi amaliahnya tidak menyimpang dari apa yang pernah dilakukan oleh Nabi SAW, para sahabat, tabi'in dan tabi'it tabi'in, tetapi apabila kelompok-kelompok tersebut berbeda dari jalan sahabat dan rasul, maka harus segera disadarkan melalui nasihat yang baik. Kelompok Salafi dalam mengahadapi persoalan-persoalan selalu mendasarkan pada teks-teks agama yakni alQuran dan As Sunnah serta tradisi yang hidup pada zaman Rasul, Sahabat, tabi'in dan tabiit tabi'in.

Pengembangan nilai-nilai toleransi terhadap kelompok keagamaan Islam lainnya terbatas pada konsep toleransi yang merupakan hasil interpretasi Salafi sendiri, yakni lebih bersifat inward looking. Apabila suatu kelompok tertentu dikategorikan sebagai pelaku bid'ah, maka tidak ada toleransi. Hal ini ditunjukkan dengan tidak mau datang dalam acara dialog atau musyawarah tentang pengembangan nilai-nilai toleransi pada kelompok aliran agama Islam, baik melalui FGD, workshop maupun ketika diadakan dialog interaktif dalam menyambut launching "Forum Komunikasi intelektual dan sosial", karena mereka khawatir terpengaruh oleh argumentasi yang dikemukakan oleh kelompok aliran keagamaan Islam lainnya. Penolakan terhadap dialog tersebut bertentangan dengan Al Quran itu sendiri, karena dapat memutus tali silaturahmi.

\section{Daftar Pustaka}

Abdullah, Taufik. "Di Sekitar Masalah Agama dan Kohesi Sosial: Pengalaman dan Tantangan". Jurnal Masyarakat dan Budaya, Vol 11, No. 1, 2009. J akarta: LIPI, Pusat Penelitian Kemasyarakatan dan Kebudayaan;

Al-Albani, Syaikh Muhammad Nashiruddin. Pernyataan Para Imam untuk Mengikuti Sunnah dan Meninggalkan yang Menyalahi Sunnah. tersedia di website http:// www. google. co. id/ search?hl=id\&source $=h p \& q=$ PERNYATAAN+PARA +MAM+UNTUK +MENGI KUTI+SUNNAH+DAN+MENINGGALKAN+YAN G+MENYALAHI+SUNNAH\&met $a=\& a q=f \& a q i$ $=\& a q l=\& o q$, diakses tanggal 7 Maret 2011; 
Fahrurrazi, Aziz. "Sistem Pendidikan Pondok Pesantren dan Tantangannya di Era Globalisasi". Mimbar Ilmiah Vol. 14, No. 2, Desember 2004. J akarta: Univ. Islam;

Hafsin, Abu. "Demokrasi di Indonesia, Antara Pembatasan dan Kebebasan". Jurnal Analisa Pengkajian Masalah Sosial Keagamaan, Vol. XVII, No. 01, J anuari-J uni 2010. Semarang: Balai Penelitian dan Pengembangan Agama;

Humsona, Rahesli. "Situasi Krisis dan Munculnya Fenomena Kekerasan". Jurnal Dinamika, Vol. 6, No. 1/2006, Surakarta: Fisip-UNS:

Jamil, Mukhsin. 2008. Agama Agama Baru di Indonesia. Yogyakarta: Pustaka Pelajar, Cet. I;

Latuconsina, Abdul Kholik. "Hukum Islam dan Eksistensi Peradilan Agama Di Indonesia, Suatu Pendekatan Sosiohistoris". J urnal Reformasi Hukum Vol. XI, No. 2, Desember 2008. J akarta: Universitas Islam;

Lubis, Todung Mulya. "Menegakkan Hak Asasi Manusia, Menggugat Diskrtiminasi". Jurnal Hukum Dan Pembangunan, Th. Ke-39, No. 1, J anuari 2009. J akarta: UI;

Mawardi, Murniati. "Corak Kerukunan Umat Kristen dan Umat Islam di Kelurahan Naikolan Provinsi NTT". Analisa J urnal Pengkajian Masalah Sosial Dan Keagamaan, Vol. XVI, No. 2, Juli-Desember 2009. Semarang: Balai Penelitian dan Pengembangan Agama;

Muhammad, Afif. "Radikalisme Agama Agama Abad 21". Al J ami' ah, J ournal of Islamic Studies, Vol. 41, Number 02, Tahun 2003. Yogyakarta: IAIN;

Muhsin, Habib. “Menggagas Komunikasi Da'wah Bil Hal Di Pedesaan". Jurnal IImu Sosial Alternatif, Vol. IX No. 2, Desember 2008, Yogyakarta: APMD;

Muhtada, Dani. "Elaborasi Syari' at Islam Dalam Konstitusi Indonesia: Paradigma Baru".
J urnal Konstitusi, Vol. I, No. 1, Agustus 2008, J akarta: PKKKD-FH Universitas Muhammadiyah Magelang, MK Rl;

Rohman, Abdul dkk., 2010. Pengembangan Nilai Nilai Toleransi Pada Kelompok Aliran Keagamaan Minoritas Di Kabupaten Banyumas. Laporan Hasil Penelitian. Purwokerto: Unsoed;

S., Zulkarnain dkk. "Model Interaksi Sosial Antarumat Beragama Studi Kasus Umat Beragama di Pulau Enggano". J urnal Istigro', Vol. 02, No. 1, 2003. Jakarta: Direktorat PTAI, Depag Rl;

Saidi, Anas. "Relasi Pancasila, Agama dan Kebudayaan, Sebuah Refleksi", J urnal Masyarakat dan Budaya, Vol 11, No. 1/2009, Jakarta: LIPI, Pusat Penelitian Kemasyarakatan dan Kebudayaan;

Schumann, Olaf. "J ihad for Whom?, The Radicalization of Religion as a Response to Political Oppression: From Turkish to Indonesian Islam". Journal of Indonesian Islam, Vol. 2, No. 02, Desember 2008. Surabaya: Program Pascasarjana-Lembaga Studi Agama dan Sosial, IAIN Sunan Ampel

Sukanta, M. "Fundamentalisme Islam Di Timur Tengah". Mimbar IImiah Th. 16, No. 2, Desember 2006. J akarta: Univ. Islam;

Thohir, Mujahirin. "Fundamentalisme Keagamaan Dalam Perspektif Kebudayaan". J urnal Analisa, Vol. XVII, No. 02 Juli-Desember 2010. Semarang: Balai Litbang Agama;

Turmudi, Endang dan Reza Sihbudi. 2005. Islam Dan Radikalisme Di Indonesia, Jakarta: LIPI Press;

Tutik, Titik Tri Wulan. "Analisis Hukum Islam terhadap Praktek Aborsi Bagi Kehamilan Tidak Diharapkan (KTD) Akibat Perkosaan Menurut Undang-Undang No. 36 Tahun 2009 Tentang Kesehatan". Jurnal Hukum Dan Pembangunan, Tahun ke-35, No. 2, April 2010. 